\title{
Penerapan Data Mining Untuk Klastering Balita Penerima Imunisasi Campak Menggunakan Metode K-Means
}

\author{
Muhammad Faisal ${ }^{* 1}$, Wiranti Sri Utami ${ }^{2}$ \\ 1,2 Program Studi Teknik Informatika, Fakultas Sains dan Teknologi, Universitas Raharja \\ E-mail: ${ }^{* 1} \underline{\text { muhammad.faisal@ raharja.info }},{ }^{2}$ wiranti.utami@ raharja.info
}

\begin{abstract}
Abstrak
Imunisasi Campak adalah imunisasi yang dilakukan untuk mencegah penyakit campak terhadap balita yang disebabkan oleh virus rubeola dan rubella, imunisasi ini diberikan mulai dari rentang usia 9 bulan hingga dewasa. Proses imunisasi ini diberikan untuk merangsang kekebalan tubuh agar kebal terhadap penyakit tersebut. Di Indonesia penyakit campak merupakan masalah yang harus dihadapi sebab dapat meningkatkan kematian pada balita. Oleh sebab itu penting bagi balita melakukan imunisasi campak untuk membentengi sistem kekebalan tubuh dari penyakit campak. Tujuan dari penelitian ini adalah untuk mengetahui balita yang sudah menerima imunisasi campak berdasarkan Provinsi dengan menggunakan data mining dan algoritma KMeans dan menggunakan dan proses perhitungan menggunakan Microsoft Excel. Penelitian ini menggunakan 34 Provinsi dengan tingkat pemberian Imunisasi campak yang sudah dilakukan oleh pemerintah.
\end{abstract}

Kata Kunci : Data Mining, Imunisasi Campak, K-Means

\begin{abstract}
Measles immunization is an immunization carried out to prevent measles in infants caused by the rubeola and rubella viruses, this immunization is given starting from the age range of 9 months to adults. This immunization process is given to stimulate the body's immunity to be immune to the disease. In Indonesia, measles is a problem that must be faced because it can increase mortality in children under five. Therefore, it is important for toddlers to immunize against measles to fortify the immune system from measles. The purpose of this study was to determine children under five who had received measles immunization by province by using data mining and the K-Means algorithm and using and calculating processes using Microsoft Excel. This study used 34 provinces with the level of measles immunization that had been carried out by the government.
\end{abstract}

Keyword : Data Mining, Measles immunization, K-Means

\section{Pendahuluan}

Imunisasi campak adalah jenis vaksin yang digunakan untuk mencegah penyakit campak. Vaksin ini termasuk kedalam program kategori rutin lengkap yang dianjurkan oleh pemerintah. Terdapat Dua jenis Vaksi campak yang digunakan untuk mencegah penyakit campak, yaitu vaksin MR dan Vaksi MMR. Vaksin MR mencegah penyakit campak dan rubella, sedangkan vaksin MMR mencegah penyakit campak, rubella, dan gondongan. Proses penelitian ini menggunakan data mining sebagai tahapan untuk melakukan analisa data yang memiliki record yang banyak berdasarkan observasi. Untuk menemukan suatu hubungan yang saling berkaitan dan dapat merangkum data yang baru sehingga data yang telah melalui proses data mining dapat di mengerti oleh pengguna. Pemanfaatan perkembangan sistem informasi memberikan dampak 
terhadap perkembangan data dengan kapasitas yang besar di berbagai bidang baik industri maupun instansi. Perencanaan pemberian imunisasi campak terhadap balita adalah salah satu program pemerintah yang sangat penting sebagai upaya pemernitah dalam menanggulangi resiko penyakit campak terhadap balita. Oleh karena itu hal tersebut akan mempengaruhi proses pengadaan, pendistrbusian, dan pemberian imunisasi campak untuk balita.

Proses penerapan menggunakan data mining akan pemberian imunisasi campak terhadap balita akan menjadi lebih efisien dan efektif sehingga imunisasi campak dapat tersedia dengan cukup dan diberikan kepada wilayah dengan tingkat imunisasi campak yang rendah. Klustering adalah bidang penelitian untuk proses analisa dan data mining. Pada tahapan klustering bagian dari data yang memiliki karakteristik yang sama akan dikelompokkan pada kelompok lain. Data mining memiliki banyak algoritma untuk proses pengelompokan klustering salah satunya adalah K-Means. Peneliti menggunakan metode K-Means karena memiliki algoritma yang sederhana dan lebih efisien.

K-Means merupakan metode pengelompokan data yang dapat membagi data kedalam dua kelompok ataupun lebih. Metode ini akan membagi data kesebuah kelompok dimana data yang memiliki karakteristik yang sama akan berada dalam satu kelompok yang sama dan data yang memiliki karaktersiti berbeda akan berada di kelompok yang berbeda. Tujuan dari pengelompokkan data yaitu untuk meminimalkan fungsi dari data yang telah disesuaikan dalam proses pengelompokkan data.

\section{Metode Penelitian}

Metode Penelitian data yang diambil dari Badan Pusat Statistik (BPS) pada tahun 2017, 2019, dan 2020.

Tabel 1. Data Balita Penerima Imunisasi Campak

\begin{tabular}{|c|c|c|c|}
\hline \multirow[t]{2}{*}{ PROVINSI } & \multicolumn{3}{|c|}{$\begin{array}{l}\text { Persentase Balita yang Pernah } \\
\text { Mendapat Imunisasi Campak } \\
\text { (Persen) }\end{array}$} \\
\hline & 2017 & 2019 & 2020 \\
\hline Aceh & 53,22 & 40,59 & 39,21 \\
\hline Sumatera Utara & 65,39 & 60,65 & 62,72 \\
\hline Sumatera Barat & 61,59 & 58,84 & 56,40 \\
\hline Riau & 65,04 & 56,45 & 60,96 \\
\hline Jambi & 67,08 & 66,92 & 63,47 \\
\hline Sumatera Selatan & 72,51 & 66,45 & 69,00 \\
\hline Bengkulu & 72,94 & 71,53 & 75,38 \\
\hline Lampung & 74,44 & 70,47 & 73,18 \\
\hline Kep. Bangka Belitung & 73,67 & 66,07 & 65,47 \\
\hline Kep. Riau & 71,28 & 74,26 & 68,47 \\
\hline Dki Jakarta & 74,40 & 72,28 & 72,82 \\
\hline Jawa Barat & 69,44 & 65,77 & 67,47 \\
\hline Jawa Tengah & 75,49 & 74,72 & 73,36 \\
\hline Di Yogyakarta & 85,45 & 79,14 & 78,67 \\
\hline Jawa Timur & 73,26 & 71,94 & 70,67 \\
\hline Banten & 66,86 & 60,17 & 58,65 \\
\hline Bali & 82,03 & 78,35 & 80,18 \\
\hline Nusa Tenggara Barat & 76,57 & 75,07 & 73,07 \\
\hline Nusa Tenggara Timur & 75,82 & 72,74 & 74,39 \\
\hline
\end{tabular}




\begin{tabular}{llll}
\hline Kalimantan Barat & 65,42 & 63,49 & 65,88 \\
\hline Kalimantan Tengah & 67,05 & 64,79 & 65,52 \\
Kalimantan Selatan & 71,14 & 68,20 & 67,89 \\
\hline Kalimantan Timur & 72,94 & 70,46 & 68,86 \\
Kalimantan Utara & 72,51 & 71,47 & 71,63 \\
Sulawesi Utara & 75,03 & 73,83 & 74,39 \\
Sulawesi Tengah & 68,58 & 66,49 & 69,85 \\
Sulawesi Selatan & 71,38 & 68,50 & 73,39 \\
Sulawesi Tenggara & 71,87 & 71,43 & 69,82 \\
Gorontalo & 76,67 & 73,68 & 75,13 \\
Sulawesi Barat & 69,29 & 67,61 & 66,76 \\
Maluku & 67,97 & 65,91 & 68,78 \\
Maluku Utara & 68,46 & 61,46 & 65,74 \\
Papua Barat & 63,47 & 64,25 & 69,08 \\
Papua & 58,77 & 55,43 & 51,84 \\
\hline
\end{tabular}

Sumber : Badan Pusat Statistik

\subsection{Literatur Review}

Untuk medukung penulisa jurnal ini maka penulis melakukan studi pustaka dari beberapa penelitian yang berkaitan dengan proses penelitian ini:

1. Penelitan yang dilakukan oleh Gustientiedina, M.Hasmil Adiya, dan Yenny Desnelita (2019) dengan judul "Penerapan Algoritma K-Means Untuk Clustering Data ObatObatan Pada RSUD Pekanbaru". Tujuan dari hasil penelitian ini adalah untuk mengetahui perencanaan kebutuhan obat-obatan baik pengadaan maupun ketersediaan pada RSUD Pekanbaru lebih efektif dan efisien dengan menggunakan metode klustering K-Means. [1]

2. Penelitian yang dilakukan oleh Asroni, Hidayatul Fitri, Eko Prasetyo (2018) dengan judul "Penerapan Metode Clustering dengan Algoritma K-Means pada Pengelompokkan Data Calon Mahasiswa Baru di Universitas Muhammadiyah Yogyakarta (Studi Kasus: Fakultas Kedokteran dan Ilmu Kesehatan, dan Fakultas Ilmu Sosial dan Ilmu Politik)". Tujuan dari penelitian ini adalah untuk mengetahui kesenjangan jumlah mahasiswa baru pada Universitas Muhamadiyah Yogyakarta dengan menggunakan klastering algoritma K-Means. [2]

3. Penelitian yang dilakukan oleh Benri Melpa Metisen, Herlina Latipa Sari (2015) dengan judul "Analisis Clustering Menggunakan Metode K-Means Dalam Pengelompokkan Penjualan Produk Pada Swalayan Fadhila" Tujuan dari penelitian ini adalah untuk mengelompokkan data penjualan dengan tingkat penjualan tinggi, sedang, dan rendah dengan menggunakan klustering dan metode K-Means. [3]

4. Penelitan yang dilakukan oleh Randi Rian Putra, dan Cendra Wadisman (2018) dengan judul "Implementasi Data Mining Pemilihan Pelanggan Potensial Menggunakan Algoritma K-Means" Tujuan penelitian ini adalah untuk implementasi pemilihan pelanggan potensial pada MC Laundry menggunakan Software Tanagra. 


\subsubsection{Proses Algoritma K-Means}

1. Melakukan proses perhitungan dari setiap data ke masing-masing klustering dan masingmasing centeroid menggunakan Euclidean Distance, dengan menggunakan rumus berikut ini:

$d(x, y)=\|x-y\|=\sqrt{\sum_{i}^{n}(x i-y i)^{2}}: i=1,2,3, \ldots n$

2. Meletakkan data ke masing-masing obyek ke dalam centeroid yang lebih dekat.

3. Melakukan proses literasi dan selanjutnya menetukan centeroid baru dengan menggunakan persamaan.

4. Bila proses centeroid belum sama ulangi langkah ketiga.

\subsubsection{Hasil dan Pembahasan}

Penelitian ini menggunakan data yang diambil dari Badan Pusat Statistik (BPS). Parameter yang digunakan adalah nama provinsi, tahun pemberian imunisasi campak 2019 dan 2020. Proses klustering dilakukan untuk mengetahui pemberian imunisasi dengan tingkat paling rendah di setiap provinsi.

1. Literasi 1

Dalam proses penghitungan nilai literasi 1 maka ditentukan nilai $\mathrm{K}$ data pusat klustering secara acak. Proses uji coba pertama ini ditentukan 3 data dengan mengambil sempel secara acak sebagai titik awal untuk melakukan proses perhitungan jarak dari seluruh kelompok kluster yang ada.

Jumlah klustering $\quad=2$

Jumlah centeroid $=6$

Jumlah atribut $=3$

Tabel 2. Data Centeroid klustering Iterasi 1

\begin{tabular}{cccc}
\hline Provinsi & \multicolumn{2}{c}{ Centeroid } & Cluster \\
\hline DKI Jakarta & 72,28 & 72,82 & $\mathrm{C} 1$ \\
\hline Yogyakarta & 79,14 & 78,67 & $\mathrm{C} 2$ \\
Banten & 60,17 & 58,65 & $\mathrm{C} 3$ \\
\hline
\end{tabular}

2. Proses selanjutnya menghitung jarak setiap masing-masing klustering centeroid menggunakan persamaan yaitu dengan Euclidean Distance.

A. Klustering $\mathrm{C} 1$

$\mathrm{C} 1$ (Aceh) $\quad=\sqrt{(40,59-72,28)^{\wedge} 2+(39,21-72,82)^{\wedge} 2=46,19}$

$\mathrm{C} 1(\mathrm{SUMUT}) \quad=\sqrt{(60,65-72,28)^{\wedge} 2+(62,72-72,82)^{\wedge} 2=15,40}$

$\mathrm{C} 1(\mathrm{SUMBAT}) \quad=\sqrt{(58,84-72,28)^{\wedge} 2+(56,40-72,82)^{\wedge} 2=21,22}$

$\mathrm{C} 1$ (Riau) $\quad=\sqrt{(56,45-72,28)^{\wedge} 2+(60,96-72,82)^{\wedge} 2=19,78}$

$\mathrm{C} 1(\mathrm{Jambi}) \quad=\sqrt{(66,92-72,28)^{\wedge} 2+(63,47-72,82)^{\wedge} 2=10,78}$

$\mathrm{C} 1(\mathrm{SUMSEL}) \quad=\sqrt{(66,45-72,28)^{\wedge} 2+(69,00-72,82)^{\wedge} 2=6,97}$

$\mathrm{C} 1$ (Bengkulu) $\quad=\sqrt{(71,53-72,28)^{\wedge} 2+(75,38-72,82)^{\wedge} 2=2,67}$

$\mathrm{C} 1$ (Lampung) $\quad=\sqrt{(70,47-72,28)^{\wedge} 2+(73,18-72,82)^{\wedge} 2=1,85}$

$\mathrm{C} 1($ Kep. Bangka $)=\sqrt{(66,07-72,28)^{\wedge} 2+(65,47-72,82)^{\wedge} 2=9,62}$ 

C1 (Kep. Riau)
$=\sqrt{(74,26-72,28)^{\wedge} 2+(68,47-72,82)^{\wedge} 2=4,78}$
C1 (Papua)
$=\sqrt{(55,43-72,28)^{\wedge} 2+(51,84-72,82)^{\wedge} 2=26,91}$

B. Klustering $\mathrm{C} 2$
C2 (Aceh)
$=\sqrt{(40,59-79,14)^{\wedge} 2+(39,21-78,67)^{\wedge} 2=55,17}$
C2 (SUMUT)
$=\sqrt{(60,65-79,14)^{\wedge} 2+(62,72-78,67)^{\wedge} 2=24,42}$
C2 (SUMBAT)
$=\sqrt{(58,84-79,14)^{\wedge} 2+(56,40-78,67)^{\wedge} 2=30,13}$
C2 (Riau)
$=\sqrt{(56,45-79,14)^{\wedge} 2+(60,96-78,67)^{\wedge} 2=28,78}$
C2 (Jambi)
$=\sqrt{(66,92-79,14)^{\wedge} 2+(63,47-78,67)^{\wedge} 2=19,50}$
C2 (SUMSEL)
$=\sqrt{(66,45-79,14)^{\wedge} 2+(69,00-78,67)^{\wedge} 2=15,95}$
C2 (Bengkulu)
$=\sqrt{(71,53-79,14)^{\wedge} 2+(75,38-78,67)^{\wedge} 2=8,29}$
C2 (Lampung)
$=\sqrt{(70,47-79,14)^{\wedge} 2+(73,18-78,67)^{\wedge} 2=10,26}$
C2 (Kep. Bangka)
$=\sqrt{(66,07-79,14)^{\wedge} 2+(65,47-78,67)^{\wedge} 2=18,58}$
C2 (Kep. Riau)
$=\sqrt{(74,26-79,14)^{\wedge} 2+(68,47-78,67)^{\wedge} 2=11,31}$
C2 (Papua)
$=\sqrt{(55,43-55.43)^{\wedge} 2+(51,84-78,67)^{\wedge} 2=35,81}$

C. Klustering $\mathrm{C} 3$

C3 (Aceh)

$=\sqrt{(40,59-60,17)^{\wedge} 2+(39,21-58,65)^{\wedge} 2=27,59}$

C3 (SUMUT)

$=\sqrt{(60,65-60,17)^{\wedge} 2+(62,72-58,65)^{\wedge} 2=4,10}$

C3 (SUMBAT)

$=\sqrt{(58,84-60,17)^{\wedge} 2+(56,40-58,65)^{\wedge} 2=2,61}$

C3 (Riau)

$=\sqrt{(56,45-60,17)^{\wedge} 2+(60,96-58,65)^{\wedge} 2=4,38}$

C3 (Jambi)

$=\sqrt{(66,92-60,17)^{\wedge} 2+(63,47-58,65)^{\wedge} 2=8,29}$

C3 (SUMSEL)

$=\sqrt{(66,45-60,17)^{\wedge} 2+(69,00-58,65)^{\wedge} 2=12,11}$

C3 (Bengkulu)

$=\sqrt{(71,53-60,17)^{\wedge} 2+(75,38-58,65)^{\wedge} 2=20,22}$

C3 (Lampung)

$=\sqrt{(70,47-60,17)^{\wedge} 2+(73,18-58,65)^{\wedge} 2=17,81}$

C3 (Kep. Bangka)

$=\sqrt{(66,07-60,17)^{\wedge} 2+(65,47-58,65)^{\wedge} 2=9,02}$

C3 (Kep. Riau)

$=\sqrt{(74,26-60,17)^{\wedge} 2+(68,47-58,65)^{\wedge} 2=17,17}$

C3 (Papua)

$=\sqrt{(55,43-60,17)^{\wedge} 2+(51,84-58,65)^{\wedge} 2=8,30}$ 
Berdasarkan hasil dari perhitungan klustering diatas maka didapatkan literasi pertama yang dapat dilihat pada tabel dibawah ini:

Tabel 3. Perhitungan Iterasi 1

\begin{tabular}{ccccc}
\hline Data $\mathbf{1}$ & $\mathbf{C 1}$ & $\mathbf{C 2}$ & $\mathbf{C 3}$ & Cluster \\
\hline 1 & 46,19 & 55,17 & 27,59 & 3 \\
\hline 2 & 15,40 & 24,42 & 4,10 & 3 \\
\hline 3 & 21,22 & 30,13 & 2,61 & 3 \\
\hline 4 & 19,78 & 28,78 & 4,38 & 3 \\
\hline 5 & 10,78 & 19,50 & 8,29 & 3 \\
\hline 6 & 6,97 & 15,95 & 12,11 & 1 \\
\hline 7 & 2,67 & 8,29 & 20,22 & 1 \\
\hline 8 & 1,85 & 10,26 & 17,81 & 1 \\
\hline 9 & 9,62 & 18,58 & 9,02 & 3 \\
\hline 10 & 4,78 & 11,31 & 17,17 & 1 \\
\hline 11 & 0,00 & 9,02 & 18,64 & 1 \\
\hline 12 & 8,43 & 17,44 & 10,45 & 1 \\
\hline 13 & 2,50 & 6,91 & 20,69 & 1 \\
\hline 14 & 9,02 & 0,00 & 27,58 & 2 \\
\hline 15 & 2,18 & 10,76 & 16,82 & 1 \\
\hline 16 & 18,64 & 27,58 & 0,00 & 3 \\
\hline 17 & 9,54 & 1,70 & 28,18 & 2 \\
\hline 18 & 2,80 & 6,92 & 20,74 & 1 \\
\hline 19 & 1,64 & 7,70 & 20,14 & 1 \\
\hline 20 & 11,20 & 20,21 & 7,96 & 3 \\
\hline 21 & 10,46 & 19,46 & 8,28 & 3 \\
\hline 22 & 6,40 & 15,36 & 12,24 & 1 \\
\hline 23 & 4,36 & 13,10 & 14,50 & 1 \\
\hline 24 & 1,44 & 10,41 & 17,21 & 1 \\
\hline 25 & 2,21 & 6,82 & 20,84 & 1 \\
\hline 26 & 6,51 & 15,42 & 12,86 & 1 \\
\hline 27 & 3,82 & 11,88 & 16,93 & 1 \\
\hline 28 & 3,12 & 11,74 & 15,86 & 1 \\
\hline 29 & 2,70 & 6,51 & 21,31 & 1 \\
\hline 30 & 7,65 & 16,58 & 11,01 & 1 \\
\hline 31 & 7,54 & 16,52 & 11,64 & 1 \\
\hline 32 & 12,93 & 21,90 & 7,21 & 3 \\
\hline 33 & 8,86 & 17,71 & 11,20 & 1 \\
\hline 34 & 26,91 & 35,81 & 8,30 & 3 \\
\hline & & & & \\
\hline
\end{tabular}


Setelah mendapatkan nilai literasi pertama selanjutnya menghitung nilai pusat kluster, pengelompokan data pada literasi pertama dan cluster awal dapat dilihat pada tabel berikut ini:

Tabel 4. Nilai Centeroid cluster 1

\begin{tabular}{cccccc}
\hline $\mathbf{X}$ & $\mathbf{Y}$ & $\mathbf{X}$ & $\mathbf{Y}$ & $\mathbf{X}$ & $\mathbf{Y}$ \\
\hline 0 & 0 & 0 & 0 & 40,59 & 39,21 \\
\hline 0 & 0 & 0 & 0 & 60,65 & 62,72 \\
\hline 0 & 0 & 0 & 0 & 58,84 & 56,4 \\
\hline 0 & 0 & 0 & 0 & 56,45 & 60,96 \\
0 & 0 & 0 & 0 & 66,92 & 63,47 \\
\hline 66,45 & 69 & 0 & 0 & 0 & 0 \\
\hline 71,53 & 75,38 & 0 & 0 & 0 & 0 \\
\hline 70,47 & 73,18 & 0 & 0 & 0 & 0 \\
\hline 0 & 0 & 0 & 0 & 66,07 & 65,47 \\
\hline 74,26 & 68,47 & 0 & 0 & 0 & 0 \\
\hline 72,28 & 72,82 & 0 & 0 & 0 & 0 \\
\hline 65,77 & 67,47 & 0 & 0 & 0 & 0 \\
\hline 74,72 & 73,36 & 0 & 0 & 0 & 0 \\
\hline 0 & 0 & 79,14 & 78,67 & 0 & 0 \\
\hline 71,94 & 70,67 & 0 & 0 & 0 & 0 \\
\hline 0 & 0 & 0 & 0 & 60,17 & 58,65 \\
\hline 0 & 0 & 78,35 & 80,18 & 0 & 0 \\
\hline 75,07 & 73,07 & 0 & 0 & 0 & 0 \\
\hline 72,74 & 74,39 & 0 & 0 & 0 & 0 \\
\hline 0 & 0 & 0 & 0 & 63,49 & 65,88 \\
\hline 0 & 0 & 0 & 0 & 64,79 & 65,52 \\
\hline 68,2 & 67,89 & 0 & 0 & 0 & 0 \\
\hline 70,46 & 68,86 & 0 & 0 & 0 & 0 \\
\hline 71,47 & 71,63 & 0 & 0 & 0 & 0 \\
\hline 73,83 & 74,39 & 0 & 0 & 0 & 0 \\
\hline 66,49 & 69,85 & 0 & 0 & 0 & 0 \\
68,5 & 73,39 & 0 & 0 & 0 & 0 \\
\hline 71,43 & 69,82 & 0 & 0 & 0 & 0 \\
\hline 73,68 & 75,13 & 0 & 0 & 0 & 0 \\
\hline 67,61 & 66,76 & 0 & 0 & 0 & 0 \\
\hline 65,91 & 68,78 & 0 & 0 & 0 & 0 \\
\hline 0 & 0 & 0 & 0 & 61,46 & 65,74 \\
\hline 64,25 & 69,08 & 0 & 0 & 0 & 0 \\
\hline 0 & 0 & 0 & 0 & 55,43 & 51,84 \\
\hline & & & & & \\
\hline & 0 & 0 & 0 \\
\hline
\end{tabular}


Dari hasil perhitungan nilai centroid diatas maka akan ditentukan nilai centeroid untuk menghitung literasi kedua, nilai centeroid pertama dapat dilihat pada tabel dibawah ini:

Tabel 5. Nilai Centeroid 1

\begin{tabular}{ccc}
\hline Klustering & \multicolumn{2}{c}{ Centeroid } \\
\hline C1 & 70,3362 & 71,1138 \\
C2 & 78,745 & 79,425 \\
C3 & 59,5327 & 59,6236 \\
\hline
\end{tabular}

3. Literasi 2

Setelah nilai centeroid dari hasil perhitungan literasi pertama telah didapatkan maka selanjutnya melakukan perhitungan literasi kedua. Hasil dari nilai literasi kedua dapat dilihat pada tabel dibawah ini:

Tabel 6. Perhitungan Iterasi 2

\begin{tabular}{ccccc}
\hline Data 2 & $\mathbf{C 1}$ & $\mathbf{C 2}$ & $\mathbf{C 3}$ & Cluster \\
\hline 1 & 43,62 & 55,44 & 27,85 & 3 \\
\hline 2 & 12,82 & 24,63 & 3,29 & 3 \\
\hline 3 & 18,67 & 30,44 & 3,30 & 3 \\
\hline 4 & 17,20 & 28,95 & 3,36 & 3 \\
\hline 5 & 8,37 & 19,86 & 8,33 & 3 \\
\hline 6 & 4,42 & 16,12 & 11,65 & 1 \\
\hline 7 & 4,43 & 8,27 & 19,80 & 1 \\
\hline 8 & 2,07 & 10,37 & 17,42 & 1 \\
\hline 9 & 7,07 & 18,85 & 8,77 & 1 \\
\hline 10 & 4,73 & 11,84 & 17,18 & 1 \\
\hline 11 & 2,59 & 9,24 & 18,35 & 1 \\
\hline 12 & 5,84 & 17,64 & 10,02 & 1 \\
\hline 13 & 4,93 & 7,28 & 20,48 & 1 \\
\hline 14 & 11,60 & 0,85 & 27,34 & 2 \\
\hline 15 & 1,66 & 11,09 & 16,61 & 1 \\
\hline 16 & 16,08 & 27,87 & 1,16 & 3 \\
\hline 17 & 12,10 & 0,85 & 27,87 & 2 \\
\hline 18 & 5,12 & 7,34 & 20,55 & 1 \\
\hline 19 & 4,06 & 7,84 & 19,81 & 1 \\
\hline 20 & 8,62 & 20,40 & 7,40 & 3 \\
\hline 21 & 7,88 & 19,70 & 7,90 & 1 \\
\hline 22 & 3,87 & 15,63 & 11,98 & 1 \\
\hline 23 & 2,26 & 13,43 & 14,31 & 1 \\
\hline 24 & 1,25 & 10,66 & 16,93 & 1 \\
\hline 25 & 4,79 & 7,04 & 20,55 & 1 \\
\hline 26 & 4,05 & 15,55 & 12,37 & 1 \\
\hline 27 & 2,92 & 11,89 & 16,43 & 1 \\
\hline 28 & 1,69 & 12,07 & 15,67 & 1 \\
\hline & & & & \\
\hline
\end{tabular}




\begin{tabular}{ccccc}
\hline 29 & 5,23 & 6,64 & 20,99 & 1 \\
30 & 5,14 & 16,86 & 10,78 & 1 \\
31 & 5,00 & 16,67 & 11,16 & 1 \\
32 & 10,38 & 22,05 & 6,41 & 3 \\
33 & 6,42 & 17,81 & 10,57 & 1 \\
34 & 24,37 & 36,12 & 8,80 & 3 \\
\hline
\end{tabular}

Nilai literasi pertama dan kedua sudah sama, maka proses perhitungan berhenti pada literasi kedua dan tidak perlu melanjutkan perhitungan ke literasi 3.

Proses klustering data balita penerima imunisasi campak dengan menggunakan metode K-Means diperoleh hasil klustering pada literasi kedua yaitu terdapat 3 kelompok dengan penerima imunisasi tinggi yaitu C3 terdapat 9 provinsi, dengan penerima imunisasi sedang yaitu $\mathrm{C} 2$ terdapat 2 provinsi dan imunisasi Sedikit $\mathrm{C} 1$ terdapat 23 provinsi.

Tabel 7. Tingkat Klusteri masing-masing Provinsi

\begin{tabular}{ll}
\hline \multicolumn{1}{c}{ Provinsi } & Cluster \\
& \\
\hline Aceh & $\mathrm{C} 3$ \\
\hline Sumatera Utara & $\mathrm{C} 3$ \\
\hline Sumatera Barat & $\mathrm{C} 3$ \\
\hline Riau & $\mathrm{C} 3$ \\
\hline Jambi & $\mathrm{C} 3$ \\
\hline Sumatera Selatan & $\mathrm{C} 1$ \\
\hline Bengkulu & $\mathrm{C} 1$ \\
\hline Lampung & $\mathrm{C} 1$ \\
\hline Kep. Bangka Belitung & $\mathrm{C} 1$ \\
\hline Kep. Riau & $\mathrm{C} 1$ \\
\hline Dki Jakarta & $\mathrm{C} 1$ \\
\hline Jawa Barat & $\mathrm{C} 1$ \\
\hline Jawa Tengah & $\mathrm{C} 1$ \\
\hline Di Yogyakarta & $\mathrm{C} 2$ \\
\hline Jawa Timur & $\mathrm{C} 1$ \\
\hline Banten & $\mathrm{C} 3$ \\
\hline Bali & $\mathrm{C} 2$ \\
\hline Nusa Tenggara Barat & $\mathrm{C} 1$ \\
\hline Nusa Tenggara Timur & $\mathrm{C} 1$ \\
\hline Kalimantan Barat & $\mathrm{C} 3$ \\
\hline Kalimantan Tengah & $\mathrm{C} 1$ \\
\hline Kalimantan Selatan & $\mathrm{C} 1$ \\
\hline Kalimantan Timur & $\mathrm{C} 1$ \\
\hline Sulawesi Utara & \\
\hline
\end{tabular}




\begin{tabular}{ll}
\hline Sulawesi Tengah & C1 \\
\hline Sulawesi Selatan & C1 \\
\hline Sulawesi Tenggara & C1 \\
\hline Gorontalo & C1 \\
\hline Sulawesi Barat & C1 \\
Maluku & C1 \\
Maluku Utara & C3 \\
\hline Papua Barat & C1 \\
\hline Papua & C3 \\
\hline
\end{tabular}

\section{KESIMPULAN}

Berdasarkan hasil dari proses klustering diatas dapat diperoleh informasi mengenai tingkat imunisasi dengan kategori rendah, sedang, dan tinggi dengan memenfaatkan algoritma K-Means.

\section{SARAN}

Dari hasil penelitian klustering menggunakal algoritma K-Means diatas mungkin bisa dilakukan penelitian lebih lanjut agar proses analisa imunisasi campak diatas dapat diperoleh hasil analisa yang lebih tepat dengan menetapkan nilai centeroid.

\section{DAFTAR PUSTAKa}

[1] Gustientiedina, M.Hasmil Adiya, dan Yenny Desnelita, 2019, Penerapan Algoritma KMeans Untuk Clustering Data Obat-Obatan Pada RSUD Pekanbaru, Vol. 05, Jurnal Naskah Teknologi dan Informasi, Universitas Andalas, Kota Padang.

[2] Asroni, Hidayatul Fitri, Eko Prasetyo, 2018, Penerapan Metode Clustering dengan Algoritma K-Means pada Pengelompokkan Data Calon Mahasiswa Baru di Universitas Muhammadiyah Yogyakarta (Studi Kasus: Fakultas Kedokteran dan Ilmu Kesehatan, dan Fakultas Ilmu Sosial dan Ilmu Politik), Vol. 21, Jurnal Semesta Teknika, Universitas Muhammadiyah Yogyakarta, Yogyakarta.

[3] Benri Melpa Metisen, Herlina Latipa Sari, 2015, Analisis Clustering Menggunakan Metode K-Means Dalam Pengelompokkan Penjualan Produk Pada Swalayan Fadhila, Vol. 5, Jurnal Media Infotama, Universitas Dehasen, Bengkulu.

[4] Benri Melpa Metisen, Herlina Latipa Sari, 2018, Implementasi Data Mining Pemilihan Pelanggan Potensial Menggunakan Algoritma K-Means, Vol. 1, Intecoms: Journal of Information Technology and Computer Science, IPM2KPE, Sumatera Selatan. 